\title{
Hari Pahlawan dan Tantangannya Bagi Pemuda
}

\author{
Oleh:
}

\section{Muhammad Arsyam, M.Pd}

(Wakil Bendahara DPD I KNPI Sulsel dan Senior Faskel P2KP Kabupaten Takalar)

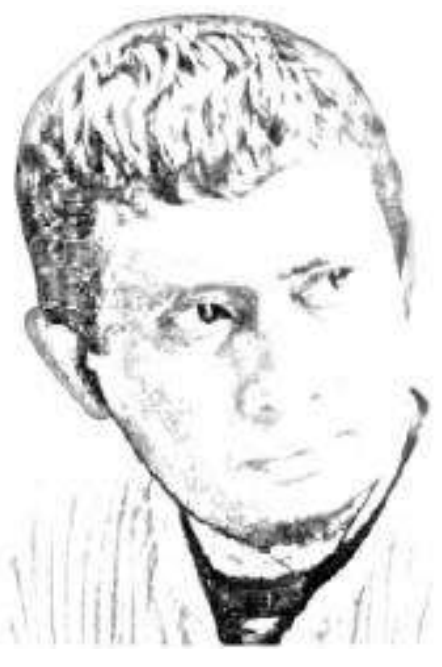

Hari Pahlawan yang selalu kita peringati hendaknya jangan hanya mengedepankan unsur seremoni belaka, tanpa menghayati nilai-nilai perjuangan yang dipesankan para pahlawan. Sungguh sangat ironi bila memeringati Hari Pahlawan, tanpa mengambil tauladan dari nilai-nilai perjuangan untuk diaplikasikan dalam kehidupan sehari-hari. Untuk itu, sebagai generasi muda, kita harus mampu memberi makna baru atas tonggak bersejarah kepahlawanan dengan mengisi kemerdekaan sesuai perkembangan zaman. Menghadapi situasi seperti sekarang kita berharap muncul banyak pahlawan dalam segala bidang kehidupan.

Bangsa ini sedang membutuhkan banyak pahlawan yakni pahlawan untuk mewujudkan Indonesia yang damai, adil dan demokratis, serta Indonesia yang bersih dan bebas korupsi. Negeri kita sedang diwarnai kasus korupsi yang sudah mencapai stadium terakhir. Karena sudah melibatkan para pejabat tinggi hingga terendah. Yang paling menyedihkan sudah melibatkan para penegak hukumnya sendiri yang semestinya mereka memosisikan diri sebagai pemberantas korupsi. Namun kini justru kebalikan dari semua itu. Indonesia sangat membutuhkan orang-orang berani untuk memberantas meningkatnya angka korupsi tersebut. Mengingat korupsi merupakan akar dari kehancuran sebuah negara.

Karakteristik seorang pahlawan adalah jujur, pemberani, dan rela melakukan apapun demi kebaikan dan kesejahteraan masyarakat. Setiap orang harus berjuang untuk menjadi pahlawan, minimal menjadi pahlawan untuk dirinya sendiri dan keluarga yang berlangsung setiap saat dalam kehidupan sehari-hari. Artinya, kita menjadi warga yang baik dan meningkatkan prestasi dalam kehidupan masing-masing. Setidaknya kita harus mampu bertanya pada diri sendiri apakah rela mengorbankan diri untuk mengembangkan diri dalam bidang kita masing-masing dan encetak prestasi dengan cara yang adil, pantas dan wajar. 
Maka, peringatan Hari Pahlawan sebaiknya dijadikan momentum bagi para pemuda sebagai hari besar yang dirayakan secara khidmat dan dengan rasa kebanggaan yang besar. Karena merupakan kesempatan bagi seluruh bangsa untuk mengenang jasa-jasa dan pengorbanan para pejuang yang tak terhitung jumlahnya dalam perjuangan bersama bagi tegaknya Republik Indonesia yang diproklamasikan 17 Agustus 1945.

Pemuda dalam momen Hari Pahlawan haruslah mengingat kembali bahwa kemerdekaan bangsa ini bukan dari hasil pemberian negara lain, tetapi hasil dari jerih payah pahlawan yang dengan rela berkorban nyawa untuk negeri. Penjajah memang tak lagi datang, tetapi bahwa model lain dari penjajahan itu sudah menjadi persoalan baru yang mesti kita perangi. Bangsa kita mengalami banyak persoalan yang menghambat arah negeri ini untuk melangkah maju ke depan. Kita seperti negara yang tidak memiliki tujuan yang pasti, terombang-ambing dengan persoalan sendiri.

Ditambah lagi sosok-sosok pemimpin di seluruh negeri ini sepertinya tidak memiliki jiwa kepahlawanan, jiwa pengorbanan atas kepentingan diri sendiri. Mereka tampaknya sibuk sendiri dengan usahanya memperkaya dan mempromosikan diri atau pencitraan. Pada momentum Hari Pahlawan ini sudah saatnyalah elite pemimpin negeri ini berhenti berbicara mengenai diri dan mereka saja. Sudah saatnya yang dibicarakan adalah bagaimana menyelamatkan negeri ini supaya bisa bertahan. Bangsa ini harus dibangkitkan kembali semangatnya untuk bangkit dan maju melawan ketertinggalan dari bangsa lain. Negara yang maju bukanlah sekadar parameter-parameter terhitung. Tapi negara maju adalah dimana semua komponen bangsa dapat bersama-sama merasakan keyakinan, kepercayaan akan masa depan bangsa yang adil, sejahtera dan damai.

Hari pahlawan tahun ini sebaiknya kita maknai sebagai hari bangkitnya semangat pengorbanan atas kepentingan diri sendiri dan membangun kepercayaan, keyakinan penuh atas harapan masa depan bangsa yang lebih baik. Memperingati Hari Pahlawan merupakan saat tepat untuk mengevaluasi ulang pemahaman akan arti pahlawan dan bagaimana memberikan makna bagi peringatan hari pahlawan itu sendiri. Jika tidak, ia hanya akan menjadi seremoni hampa yang tidak bermakna. Untuk itu, khususnya kepada generasi muda sekarang harus berani memerangi kebodohan, keterbelakangan, kemiskinan termasuk juga persoalan korupsi, jika anak-anak bangsa sudah memiliki tingkat pendidikan yang baik dan memiliki skill yang dapat dihandalkan maka angin perubahan di negeri tercinta ini akan lebih cepat bergerak maju. Setidaknya jasa-jasa para pahlawan yang telah berkorban demi sebuah kemerdekaan 
bagi bangsa ini tidak akan sia-sia. Yang terpenting selain itu, bagaimana generasi penerus saat ini memiliki visi ke depan. Sehingga tidak terjebak dengan arus globalisasi yang serba cepat dan terkadang menghilangkan norma-norma budaya bangsa ini.

Nah, jika kita memiliki impian-impian yang baik ke depan, maka segala hal yang dapat merusak baik untuk diri, keluarga, masyarakat maupun secara luas bagi bangsa Indonesia tidak akan dilakukan. Dan satu yang terpenting yaitu bagaimana semangat juang para pahlawan yang telah gugur dapat diimplementasikan dalam kehidupan seharihari. Sebab, perubahan menuju kesejahteraan tidak akan dapat diraih dengan hanya berdiam diri, tetapi bagaimana perubahan tersebut dapat diraih dengan semangat yang membaja dan pantang menyerah serta semangat kepahlawanan. $\left(^{*}\right)$

Artikel ini telah tayang di tribun-timur.com dengan judul Hari Pahlawan dan Tantangannya Bagi Pemuda, https://makassar.tribunnews.com/2015/11/10/hari-pahlawan-dan-tantangannya-bagipemuda.

Editor: Aldy 